\title{
Sucesso e ambientes institucionais favoráveis a projetos de democracia digital: uma análise a partir do Gabinete Digital (Rio Grande do Sul)
}

\author{
Success and institutional environments favorable to e-democracy \\ projects: an analysis of the Digital Office (Rio Grande do Sul)
}

\author{
Vinicius $\mathrm{Wu}$ \\ Rafael Cardoso Sampaio
}

\section{Resumo}

O objetivo deste artigo é analisar o ambiente institucional e a capacidade de interferência sobre o processo decisório governamental do Gabinete Digital - experiência de democracia digital desenvolvida no estado do Rio Grande do Sul entre 2011 e 2014 - de modo a contribuir com o debate a respeito da avaliação de iniciativas de democracia digital no Brasil. Para tanto, optou-se por uma abordagem sistêmica ao objeto, ao mesmo tempo em que foram analisados alguns dos aspectos que caracterizaram a instituição participativa em questão. A mobilização institucional, a transversalidade de temas e a adesão do corpo de servidores são destacadas a fim de se avaliar até que ponto a experiência obteve êxito em movimentar o aparato estatal para assegurar efetividade aos processos de participação.

\section{Palavras-chave}

E-Participação; Democracia Digital; Inovação Democrática; Instituição Participativa.

\begin{abstract}
The objective of this article is to analyze the institutional environment and the capacity of interference on the governmental decision-making process of the Digital Office - e-democracy experience developed in the state of Rio Grande do Sul between 2011 and 2014 - to contribute to the debate regarding the evaluation of digital democracy initiatives in Brazil. To this end, a systemic approach to the object was chosen, while analyzing some of the aspects that characterized the participatory institution in question. Institutional mobilization, the transversality of themes, and adherence to the body of servants are highlighted to assess the extent to which the experience was successful in moving the state apparatus to ensure effectiveness in the participation processes.
\end{abstract}

\section{Keywords}

E-Participation; E-democracy; Democratic Innovation; Participatory Institution. 


\section{Introdução}

Entre os diferentes experimentos de democracia digital realizados no Brasil até o presente momento, poucos obtiveram êxito em suplantar - ou ao menos em reduzir - os inúmeros constrangimentos verificados junto ao aparato estatal, ao desenvolvimento de iniciativas dessa natureza. A resistência institucional costuma isolar ou reduzir os efeitos práticos das experiências de participação por meio digital desenvolvidas por diferentes órgãos do Estado brasileiro. Ela funciona como uma espécie de salvaguarda para os agentes do sistema político menos interessados em absorver o custo da participação, facilitada pelos meios digitais (AGGIO e SAMPAIO, 2014).

As iniciativas que efetivamente lograram mobilizar o aparato estatal para o atendimento - ainda que parcial - de demandas que emergiram na cena pública através de mecanismos digitais de participação foram aquelas que, de alguma forma, ao associarem fatores como vontade política e visibilidade (SMITH e MACINTOSH, 2007) despertaram no público a expectativa de uma maior influência nas decisóes que governam suas vidas (COLEMAN e BLUMLER, 2009). Gerou-se, a partir daí, algum tipo de pressão sobre o Estado no sentido de oferecer respostas efetivas aos grupos sociais e a parcelas da sociedade envolvidas em processos dialógicos ou de participação mediados por tecnologias digitais.

Dentre os inúmeros fatores que parecem ter contribuído para a efetividade de algumas das iniciativas de democracia digital desenvolvidas no Brasil, está algo que aqui chamaremos de capacidade de coordenação - determinada por fatores como mobilização institucional, adesão do corpo de servidores, localização privilegiada e vontade política (AGGIO e SAMPAIO, 2014). Portanto, a capacidade de coordenaçáo, ou seja, a capacidade dos experimentos de democracia digital em vencer resistências institucionais, mobilizar o aparato estatal e incidir sobre suas estruturas para produzir respostas efetivas à participação da sociedade parece ser um elemento chave à compreensão do êxito e do fracasso de iniciativas na área.

Assim, esse trabalho propóe uma análise sobre os diferentes aspectos que costumam determinar a obtenção - ou não - de suficiente capacidade de coordenaçáo por parte das experiências de democracia digital. Considera-se, portanto, que, para além de outros fatores, o sucesso de iniciativas de democracia digital guarda estreita relação com sua capacidade de mobilização institucional e a força política que elas conseguem adquirir no curso de sua consolidaçáo. Estes são dois condicionantes fundamentais para que as experiências de democracia digital possam superar - ainda 
que parcialmente - a força das instituiçôes profundas (FOUNTAIN, 2001), que inibem o florescimento e a consolidação de novos arranjos democráticos junto ao aparato estatal.

A reflexão proposta pelo presente trabalho dialoga com uma preocupação pouco visitada na literatura brasileira acerca de fatores internos de sucesso e fracasso de iniciativas de democracia digital, notadamente de participação eletrônica (ou eparticipação). A experiência que servirá de referência para a verificação dessa hipótese será o Gabinete Digital do Rio Grande do Sul, criado pelo governo do Estado do Rio Grande do Sul em 2011 e em funcionamento até o ano de 2014. Ao longo dos quatro anos de existência, o projeto foi capaz de atrair um número considerável de participantes em suas diferentes práticas de consulta e conversação política. Vencedor de diversos prêmios - incluindo o Prêmio Bank Beneficiary Feedback Awards, do Banco Mundial e o Prêmio ao Serviço Público da ONU - o Gabinete Digital pode ser considerado uma das mais relevantes experiências de democracia digital desenvolvidas no país, obtendo substanciais resultados em termos de comunicação pública, interação entre governo e cidadáos, acesso à informação, transparência, influência do cidadão (AGGIO e SAMPAIO, 2014; BAUMGARTEN, 2016; BRISOLA et al., 2012; COCCO, 2013; JERÔNIMO, 2016; ROTENBERG, 2014; SANTOS et al., 2015), tendo se tornado referência para outras administraçôes, incluindo a própria Presidência da República e prefeituras em diferentes regiôes do país (RODEGHERI e OLIVEIRA, 2014).

Para que sejam alcançados os objetivos descritos anteriormente, o presente trabalho será baseado em um estudo de caso do Gabinete Digital (GD), que tentará reunir o máximo de dados primários ou secundários sobre a iniciativa. Em outras palavras, faremos uma pesquisa descritiva-qualitativa baseada em três tipos principais de dados: 1) resultados de relatórios internos e externos de pesquisas realizadas com os funcionários públicos do estado do Rio Grande do Sul, à época do GD; 2) resultados externos e públicos das consultas públicas realizadas pelo GD e 3) documentos internos da gestão de matriz de processos do governo do estado no que tange o GD (FGV, 2011, 2012a, 2012b, 2014). Boa parte destes dados foram utilizados apenas para consumo interno do governo à época e permaneceram inéditos até o momento. 


\section{Democracia Digital e os fatores de sucesso de iniciativas de e- participação}

Este artigo busca aprofundar, no âmbito dos estudos sobre democracia digital, as discussóes a respeito de fatores de sucesso para e-participação. Para nossos interesses, pode-se entender democracia digital (ou e-democracia) como um campo que lida com a complexa relação entre tecnologias digitais de comunicação e práticas democráticas ou, mais especificamente, com "o emprego de tecnologias digitais de comunicação com o objetivo de corrigir, incrementar ou incorporar novos procedimentos ao processo político, no sentido de melhor atender a um ou mais princípios da democracia" (ALMADA et al., 2019, p. 163). Portanto, em seu sentido mais prático, a democracia digital é baseada em experiências práticas que devem buscar solucionar problemas reais do sistema político através de aplicaçóes, projetos e iniciativas em seu sentido amplo (GOMES, 2011). À exemplo de Smith (2009) e Spada e Allegretti (2017), consideramos que projetos relevantes de democracia digital são exemplos de inovação democrática (FREITAS, 2021) e se aproximam das interfaces socioestatais tratadas pela literatura de instituiçóes participativas no Brasil (LÜCHMANN, 2020).

Dito isso, a partir da análise de uma experiência com significativo grau de reconhecimento na área, este trabalho apresenta algumas hipóteses para a compreensão a respeito das condiçóes políticas e institucionais necessárias ao aumento do sucesso dos programas de democracia digital e, inicialmente, debruça-se sobre a literatura que analisa fatores de sucesso de iniciativas de e-participação.

Segundo Toots (2019), enquanto instrumentos para diálogo democrático, sistemas de e-participação podem ter diferentes objetivos para serem considerados bemsucedidos, e os mais acionados pela literatura seriam: facilitar o diálogo deliberativo entre governantes e cidadãos, aumentar a participação cidadã nas tomadas de decisão, incrementar a confiança do público, fortalecer a legitimidade de processos democráticos e incrementar a qualidade e o sucesso de políticas públicas. A reprodução de mecanismos e procedimentos institucionais já consagrados, bem como de suas dinâmicas de funcionamento pré-existentes, tem sido apontada como um dos grandes problemas dos projetos de democracia digital que, dessa forma, terminam por não proporcionar mudanças reais nos processos políticos (COLEMAN e BLUMLER, 2009).

As iniciativas de democracia digital, portanto, se veem diante da necessidade não somente de ampliar a participação social e sua credibilidade, como também de sofisticá-la, tendo em vista as novas opçóes tecnológicas e o maior acesso da esfera civil 
e do sistema político a tais ferramentas. Para tanto, parece-nos que determinados fatores para sucesso ou efetividade das iniciativas precisam ser mais bem avaliados, notadamente os relacionados aos fatores internos em termos institucionais $\mathrm{e}$ burocráticos.

$\mathrm{Na}$ literatura especializada sobre e-participação, uma interessante lista de fatores de sucesso é levantada por Smith e Macintosh (2007) baseada na avaliação de vários projetos de e-participação da União Europeia, nomeadamente: 1) Agenda compartilhada (um tema forte ou objetivo bem definido); 2) Agenda definida; 3) Tecnologia cuidadosamente estruturada; 4) Facilitação forte e ativa; 5) grupos pequenos; 6) ímpeto para apoiar um bom uso de fóruns (online ou não); 7) uso de tecnologia aberta; 8) boa publicidade e 9) apoio/vontade política.

Nessa seara, Aström e Grönlund (2012) fazem uma revisão de vários artigos com estudos de caso de iniciativas de e-participação (especificamente, de consultas online) na Europa e nos Estados Unidos. Fazendo uso de princípios de revisáo sistemática de literatura, os autores buscam compreender quais os fatores mais associados ao sucesso pelas pesquisas originais. Após testes estatísticos, tendo a ideia de sucesso como variável dependente, eles destacam: intenções democráticas, comprometimento ao processo, fase da política pública na qual ocorre a consulta (i.e. tomada de decisáo), modo de comunicação mais deliberativo; mistura de métodos online e presencial e seleção de participantes de forma aleatória ou estratégica (i.e. não é aberta a todos participantes).

Porém, é notável que ambas as pesquisas acabam se detendo mais sobre o desenho institucional dos mecanismos e projetos de e-participação que de fato sobre os fatores institucionais internos. Segundo nosso levantamento, a pesquisa de Panopoulou, Tambouris e Tarabanis (2014) pode ser considerada a mais ampla e compreensiva em termos de fatores de sucesso. Além de uma revisão sistemática da literatura de e-participação e governo eletrônico por fatores de sucesso, os autores conduzem um questionário online entre promotores de iniciativas de e-participação, comparando o resultado dos dois estudos como forma de validar os dados. Os autores apontam 23 diferentes principais fatores de sucesso. Apesar de vários fatores remeterem às questôes internas que mais nos interessam neste trabalho, o problema, como demonstrado por Zimmermann (2018), é que se trata de um número muito grande de variáveis e os autores apenas apresentaram a lista e não como aplicá-los adequadamente. 
Apesar de não serem táo compreensivos como Panopoulou et al. (2014), a pesquisa de Vidiasova, Trutnev e Vidiasov (2017) elenca um conjunto razoável de fatores que influenciam o desenvolvimento de projetos de e-participação na Rússia. Com base em um estudo realizado com proponentes de iniciativas de e-participação no país, os autores apresentam algumas recomendaçôes para superar as principais barreiras: a) envolver diretamente os servidores públicos com as ferramentas; b) estabelecer a responsabilidade desses servidores em dar respostas no tempo adequado aos cidadãos participantes; c) aumentar os benefícios e a motivação desses cidadáos para o uso das ferramentas e d) providenciar, necessariamente, uma rápida resposta às demandas dos participantes através de sistemas de alerta.

Por sua vez, Toots (2019) está particularmente interessada em entender as falhas de sistemas de e-participação e busca compreendê-las através de um estudo de caso de uma iniciativa da Estônia. Não obstante, a autora faz um levantamento bastante abrangente de fatores contextuais de sucesso e de falha. No que tange ao contexto institucional, Toots (2019) destaca que vários interessados dentro da organização participam dos projetos, entâo é preciso se lembrar de que organizaçóes do setor público possuem características distintivas que restringem suas habilidades de integrar novas práticas, o que inclui objetivos ambíguos ou mesmo em competição dificuldade de se equilibrar os diferentes interesses em questão, complexidade estrutural e legal, suscetibilidade a interesses políticas, e influência de tradiçôes de governança. Todas essas características enfatizam a importância de indivíduos ou organizaçóes no setor público que funcionam como promotores de inovação e agentes de mudança (Faria et al., 2016).

Não obstante, já há alguma literatura acumulada acerca do Gabinete Digital do Rio Grande do Sul. Há um certo consenso da literatura que se trata de um caso de sucesso em termos de democracia digital e notadamente de e-participação (como apresentaremos na seção seguinte), uma vez que a plataforma obteve bons resultados em números de participantes em seguidas consultas públicas. A grosso modo, a literatura ressaltou alguns pontos a serem incrementados no GD, como i) ausência de mecanismos mais complexos de participaçáo (e.g. ferramentas para deliberação); ii) resistência política e também institucional; iii) falta de clareza sobre o efetivo impacto da participação nas políticas públicas; iv) falta de integração do GD com outros arranjos participativos do estado do RS e mesmo de municípios; v) carência de maior institucionalização da iniciativa; vi) pouco poder de agendamento por parte do cidadão (BAUMGARTEN, 2016; BRISOLA et al., 2012; RODEGHERI e OLIVEIRA, 
2014). Por sua vez, Aggio e Sampaio (2014) realizam uma reflexão acerca do que defendem ser os quatro principais fatores de sucesso da iniciativa, que parecem resumir os principais pontos levantados pela literatura, nomeadamente: 1) ampla vontade política e localização privilegiada; 2) participação e promoção em eventos e relação com os mídia massivas; 3) participação pelo viés da simplicidade e da customização; 4) Cultura participativa do RS (além de um apoio específico de coletivos da sociedade civil, como detalhado por Baumgarten (2016)).

O objetivo desse artigo é ampliar esses aspectos institucionais já ressaltados pela literatura, especialmente no que tange o desenvolvimento de questôes, dificuldades e soluçóes internas à gestáo da iniciativa de democracia digital, elementos que frequentemente são deixados em segundo plano por estudos e reflexôes que estão, geralmente, avaliando apenas o momento ou o produto final do processo participativo.

\section{O caso do Gabinete Digital do Rio Grande do Sul}

Como já mencionado, o Gabinete Digital foi uma iniciativa de democracia digital que funcionou entre 2011 e 2014 no âmbito do governo do estado do Rio Grande do Sul, durante a gestão de Tarso Genro do Partido dos Trabalhadores (PT). A primeira versão do projeto foi lançada em maio de 2011 e possuía três canais de participação: Agenda Colaborativa, Governo Escuta e Governador Responde. O primeiro possibilitava aos cidadáos opinarem sobre a agenda do governador em seus deslocamentos pelo interior do estado. $\mathrm{O}$ segundo apresentava-se como uma audiência pública digital, realizada periodicamente, na qual eram debatidos temas de interesse geral. E, finalmente, o canal mais destacado da primeira etapa era o Governador Responde, uma ferramenta por meio da qual a sociedade podia lançar questionamentos ao governador, que respondia pessoalmente à questão mais votada a cada mês e buscava proporcionar uma espécie de atendimento ao autor (es) da pergunta escolhida. Posteriormente, novos canais foram incorporados, notadamente, o Governador Pergunta (no qual o governo lançava uma consulta pública na forma de uma pergunta e propostas eram sugeridas e priorizadas pelo público) e o De Olho nas Obras (ferramenta de transparência e controle social sobre a execução de obras públicas).

A seguir, são destacados alguns aspectos internos que aparentam ter sido decisivos para o desenvolvimento do projeto, quais sejam, Transversalidade e diversidade de temas (o que parece ter não apenas contribuído para uma maior mobilização interna, mas também servido como estímulo à participação, resultando 
numa significativa variedade de temas abordados pela cidadania); a mobilização institucional e sua localizaçáo privilegiada (o que permitiu ao Gabinete Digital movimentar o governo para oferecer respostas à sociedade) e, finalmente, a adesáo dos servidores e dirigentes do governo (o que teria sido importante para a internalizaçáo dos procedimentos suscitados pela dinâmica de participação). Todos esses aspectos somados contribuíram para reforçar a capacidade de coordenaçáo do projeto, entendida como a capacidade de articular as estruturas de governo, mobilizar recursos administrativos e sensibilizar gestores e servidores para o atendimento das demandas oriundas da participação por meio digital ${ }^{1}$. A análise considera este um elemento fundamental para a efetividade das experiências de democracia digital.

\section{Transversalidade e diversidade de temas}

Nos primeiros meses da experiência (2011), a ferramenta Governador Responde foi a que não só obteve maior destaque e visibilidade, como também contou com um número maior de adesóes. Logo no primeiro mês, a plataforma obteve 6.637 votos e recebeu 205 questionamentos a respeito de variados temas. O sistema de funcionamento da ferramenta era bastante simples e facilmente assimilável: as perguntas eram de iniciativa da sociedade e os temas eram livres. Elas eram submetidas a uma votaçáo e a que recebesse mais votos era respondida pessoalmente pelo governador, que também anunciava medidas para garantir o atendimento da questão por parte do governo.

O Gabinete Digital poderia, a seu critério, consolidar perguntas semelhantes em benefício do processo de diálogo. Cada rodada de avaliação de perguntas e votos possuía 30 dias. As respostas subiam na plataforma até 10 dias após a contabilização de votos, pois a produçáo da resposta envolvia a participaçáo direta das unidades responsáveis pelo tema escolhido. Cada tema abordado não poderia se repetir nas três rodadas seguintes, de modo a náo restringir o diálogo.

Um dos fatores que ajudam a explicar o êxito inicial da plataforma foi a diversidade de temas que ela se propôs a absorver. Ao contrário de outras experiências de democracia digital, o Gabinete Digital não esteve circunscrito a uma ou outra área de governo e, ao contrário, poderia envolver qualquer área do governo. As perguntas

\footnotetext{
${ }^{1}$ Fountain (2001) ao refletir sobre a construção de um estado digital no início dos anos 2000 já tratava do impacto da internet na coordenação de agentes burocráticos. Trata-se, ao nosso ver, de tema pouco explorado.
} 
cadastradas no sistema do Governador Responde eram agrupadas em torno de 20 temas relacionados às políticas públicas (conforme Tabela 1).

A possibilidade de que temas bastante diversos pudessem ser abordados parece ter sido fundamental para definir o perfil dos participantes e o comportamento dos usuários da plataforma. Como pode ser observado na Tabela 1, há grande variedade nos temas das perguntas levantadas pelos participantes, apesar da concentração nos três primeiros temas (valorização do servidor, segurança pública e educação). A votação era pública e a plataforma permitia ao participante identificar qual tema estava sendo mais votado. Portanto, o usuário poderia votar numa questáo que já tivesse apoio considerável ou cadastrar sua própria pergunta. Além disso, mesmo percebendo que teria de começar a conquistar votos do zero, muitos optaram por levantar sua própria questáo. Isso parece indicar que um número considerável dos que acessaram a plataforma, mobilizados por um tema específico, não o fariam se apenas tivessem a opçấo de "votar" em um tema que não era de seu interesse. Os dados referentes à distribuição regional das perguntas e dos votos parecem reforçar a ideia de que a abertura a vários temas contribuiu para a adesão inicial à plataforma.

A tabela a seguir foi produzida a partir de método quantitativo aplicado sobre o banco de dados do Gabinete Digital entre os meses de maio e outubro de 2011. A análise de conteúdo buscou enquadrar as questóes entre as categorias relacionadas pela plataforma para a agregação das perguntas cadastradas.

Tabela 1 - Grade de categorização de temáticas do GD

\begin{tabular}{l|l}
\hline Categoria & Percentual \\
\hline Valorizaçáo do Servidor & 34,5 \\
\hline Segurança Pública & 13,3 \\
\hline Educação & 10,1 \\
\hline Estradas & 4,7 \\
\hline Tecnologia da Informaçáo & 4,5 \\
\hline Saúde & 3,6 \\
\hline Meio Ambiente e Saneamento & 3,2 \\
\hline Agricultura & 2,4 \\
\hline Juventude & 2,1 \\
\hline Cultura & 1,9 \\
\hline Enfrentamento às drogas & 1,9 \\
\hline Segurança no trânsito & 1,7 \\
\hline Energia & 1,3 \\
\hline
\end{tabular}




\begin{tabular}{l|l}
\hline Acessibilidade & 1,3 \\
\hline Esporte & 0,9 \\
\hline Petróleo, Gás Natural e Pólo Naval & 0,9 \\
\hline Enfrentamento às calamidades climáticas & 0,6 \\
\hline Combate à miséria & 0,6 \\
\hline Habitaçáo & 0,4 \\
\hline Mulheres & 0,2 \\
\hline Outros & 9,7 \\
\hline
\end{tabular}

Fonte: $1^{\circ}$ Relatório de Monitoramento da Implementação e Avaliação do Gabinete Digital (2011).

$\mathrm{Na}$ distribuição regional, percebe-se que, apesar da participação preponderante da região metropolitana - em termos tanto de perguntas cadastradas quanto de participação absoluta pelo voto - há uma distribuição razoável entre as regiôes do estado, conforme os Gráfico 1 e 2, que indica a votaçáo alcançada em cada Conselhos Regionais de Desenvolvimento (COREDE), que correspondem a diferentes regióes administrativas do estado do Rio Grande do Sul. Uma hipótese para a compreensão desse resultado seria a possibilidade de acessar a plataforma a partir de pautas de interesse local. 
Gráfico 1 - Número de perguntas por Corede

\section{Coredes $/ N^{\circ}$ Perguntas}

Metropolitano Delta do Jacuí
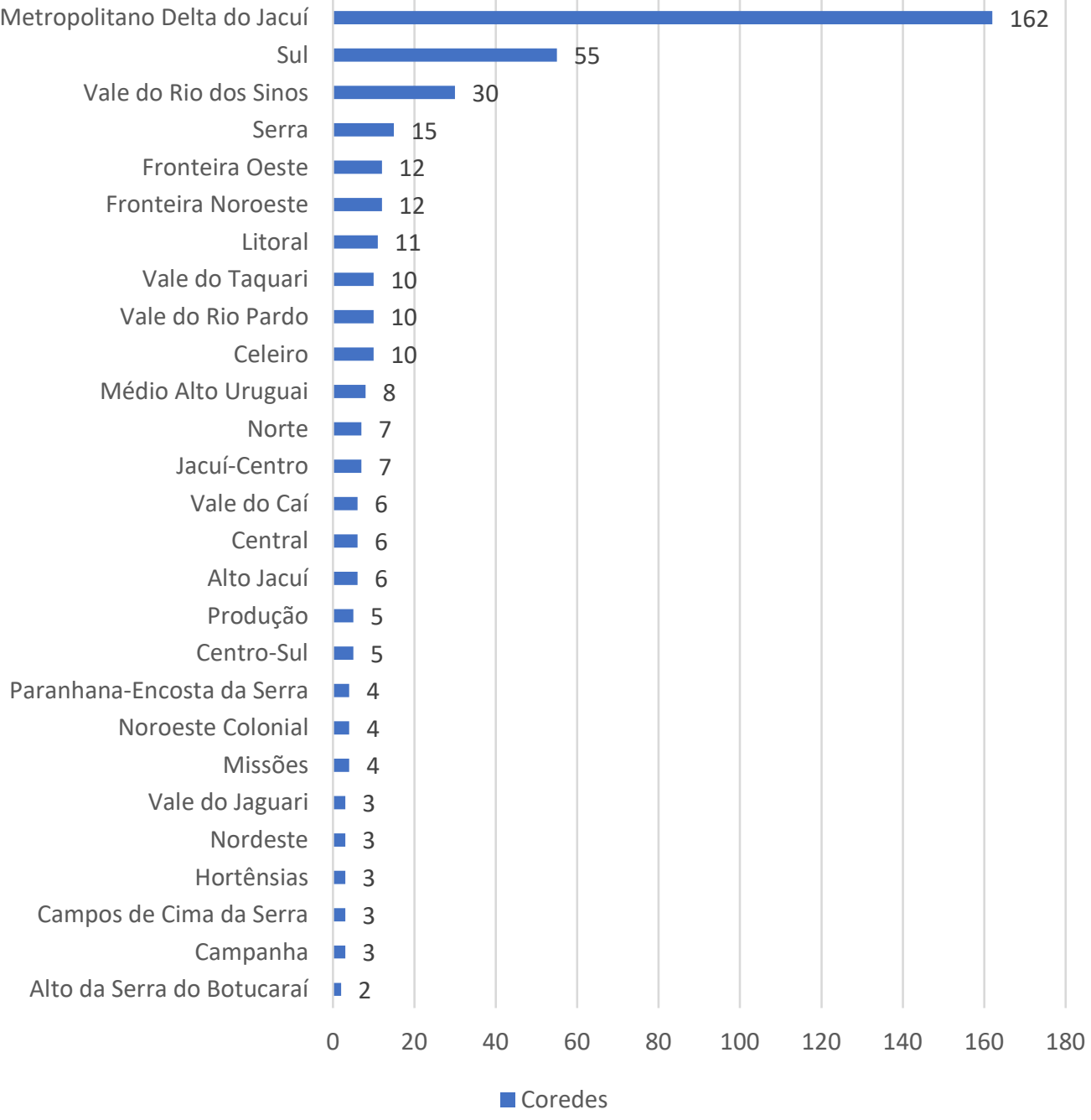

Fonte: $1^{\circ}$ Relatório de Monitoramento da Implementação e Avaliação do Gabinete Digital (2011). 
Gráfico 2 - Número de votos por Corede

\section{Coredes $/ \mathrm{N}^{\circ}$ Votos}

Metropolitano Delta do...

Medio Alto Uruguai

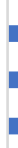

Vale do Rio dos Sinos

Central

Serra

Serra

Produção

Litoral

Alto da Serra do Botucaraí

Vale do Rio Pardo

Alto Jacuí

Fronteira Noroeste

Fronteira Oeste

Missões

Vale do Jaguari

Norte

Noroeste Colonial

Vale do Caí

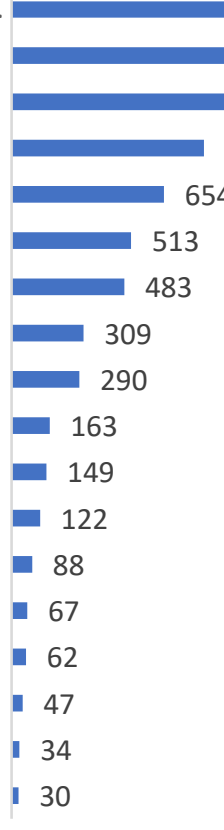

0

1000

654

\section{3}


Gráfico 3 - Evolução do cadastro de perguntas na ferramenta Governador Responde (maio-outubro 2011)

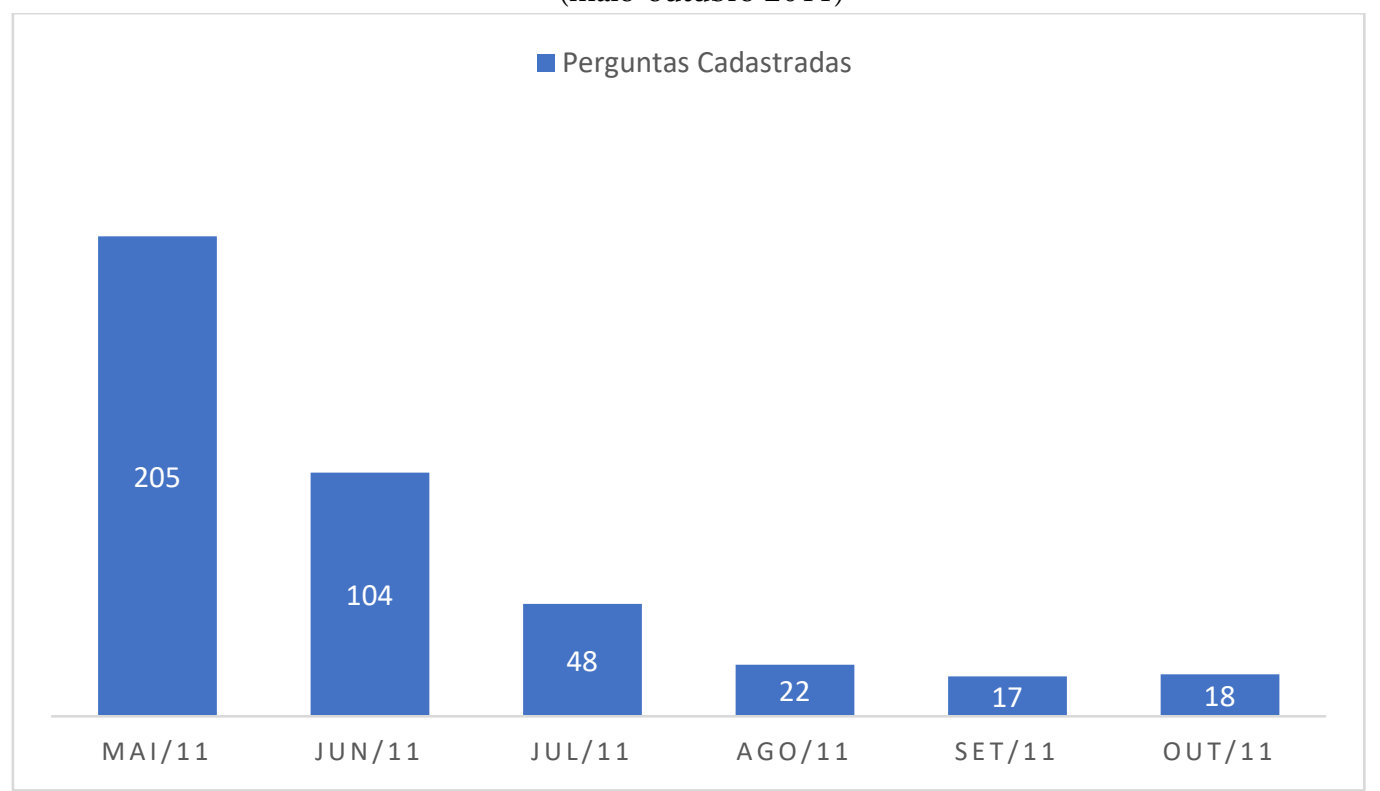

Fonte: $1^{\circ}$ Relatório de Monitoramento da Implementação e Avaliação do Gabinete Digital (2011).

Como forma de reverter a queda do número de participaçóes, os gestores do Gabinete Digital decidiram, então, adotar um novo canal, o Governador Pergunta, que possibilitou ao governo do Rio Grande do Sul realizar consultas públicas online com maior volume de participação. Se antes o público era chamado a perguntar, agora era o governo que lançava uma determinada questáo e recolhia contribuiçóes durante um determinado período. O primeiro tema debatido no âmbito do Governador Pergunta foi saúde pública.

A nova ferramenta intensificou o processo de mobilização transversal do governo, demandando um comprometimento ainda maior de uma das principais áreas de atuação do poder público estadual, a saúde. Segundo o Relatório Técnico Parcial de Estudo Comparativo elaborado pela Fundação Getúlio Vargas, FGV: 
mais de sessenta mil pessoas foram mobilizadas em atividades da primeira edição do "Governador Pergunta" entre os dias 9 de novembro e 9 de dezembro de 2011. Cerca de 20 mil pessoas participaram em atividades presenciais da consulta, que incluíam reuniōes com movimentos sociais e lideranças na área de saúde pública e palestras e atividades em diversos municípios gaúchos, entre eles: Pelotas, Erechim, Caxias, Santa Maria, Cacequi, Bento Gonçalves, Santa Cruz, Santo Angelo, Ijuí e Palmeira das Missōes (FGV, 2014, p.14).

Em todos os eventos, o Gabinete Digital solicitou à Secretaria de Saúde o envio de técnicos e especialistas que debateram diretamente com a população os termos da consulta. A própria Secretaria de Saúde disponibilizou e adaptou um veículo que circulava pelo estado e buscava ampliar as possibilidades de acesso do público à consulta. A FGV estimou em 10 mil o número de participantes mobilizados a partir deste equipamento. Também foram instalados pontos de acesso com computadores exclusivamente dedicados à consulta em oito espaços públicos da capital e sete telecentros no interior do estado. O importante, neste ponto, é ressaltar a capacidade demonstrada pelo Gabinete Digital em realizar uma ação transversal, com forte colaboração de áreas finalísticas do governo como a saúde.

O processo de consulta do Governador Pergunta foi estruturado em duas etapas. Na primeira, os usuários poderiam cadastrar suas propostas em torno de temas específicos referentes ao atendimento na área da saúde. $\mathrm{Na}$ segunda etapa, as proposiçôes eram votadas e priorizadas, resultando em 50 proposiçôes prioritárias. $\mathrm{O}$ projeto procurou "traduzir" termos técnicos através de sentenças simples na estrutura da nova consulta, conforme demonstrando pelas Figuras 1-3 (BRISOLA et al., 2012). A obtenção de dados e informaçóes para subsidiar o processo de consulta e a própria elaboração das questôes e dos formulários apresentados ao público na ferramenta somente foram possíveis com base na mobilização do corpo técnico da Secretaria de Saúde do estado (FGV, 2014), o que reforça a percepçáo de que a consulta foi fruto de um processo construído de maneira transversal e integrada. 


\section{Figura 1 - Apresentação do Governador Pergunta}

\section{O que é?}

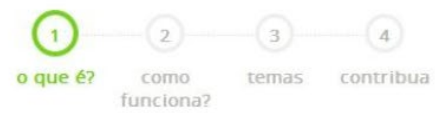

No Governador Pergunta qualquer pessoa pode responder a uma grande questão levantada pelo Governador e contribuir para a discussão de temas importantes para a população.

Na primeira edição, discutiremos o tema Saúde, respondendo "o que podemos fazer para melhorar o atendimento na saúde pública?".

É muito fácil enviar sugestões. São as suas ideias que ajudarão a gerar subsídios para o aprimoramento e o desenvolvimento de políticas públicas nas áreas mais importantes para nosso Estado.

contribua

como funciona? ••>

\section{Fonte: Relatório da Sistemática do Diálogo “O Governador Pergunta” (2012a).}

Figura 2 - Funcionamento do Governador Pergunta

\section{Como funciona?}

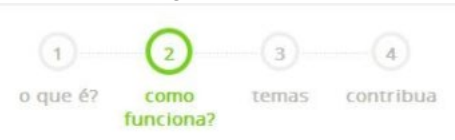

O governador elabora uma pergunta e realiza uma assembleia com transmissão ao vivo pela internet para discutir o assunto. É a oportunidade de interagir com ele, tirar dúvidas e fazer sugestões.

É o periodo de envio de propostas. Você escolhe entre cinco temas

estratégicos para a Saúde e envia sua sugestão até o dia 24 de novembro.

É o período de votação. As propostas enviadas serão sistematizadas e apresentadas para votação a partir do dia 25 de novembro até o dia 9 de dezembro. Qualquer cidadão pode votar e escolher as que considera mais importantes. Duas propostas sobre o mesmo tema são apresentadas lado a lado para que o participante priorize uma em relação à outra. Novos pares de propostas sobre temas diferentes são então apresentadas sucessivamente.

1. No dia 14 de dezembro os autores das 50 propostas mais votadas (dez de cada tema) terão um encontro com o Governador no Palácio Piratini, para discutir suas contribuições.

$$
\langle\bullet \text { o que é? temas } \bullet\rangle
$$

Fonte: Relatório da Sistemática do Diálogo “O Governador Pergunta” (2012a). 
Figura 3 - Cadastro de Propostas do Governador Pergunta

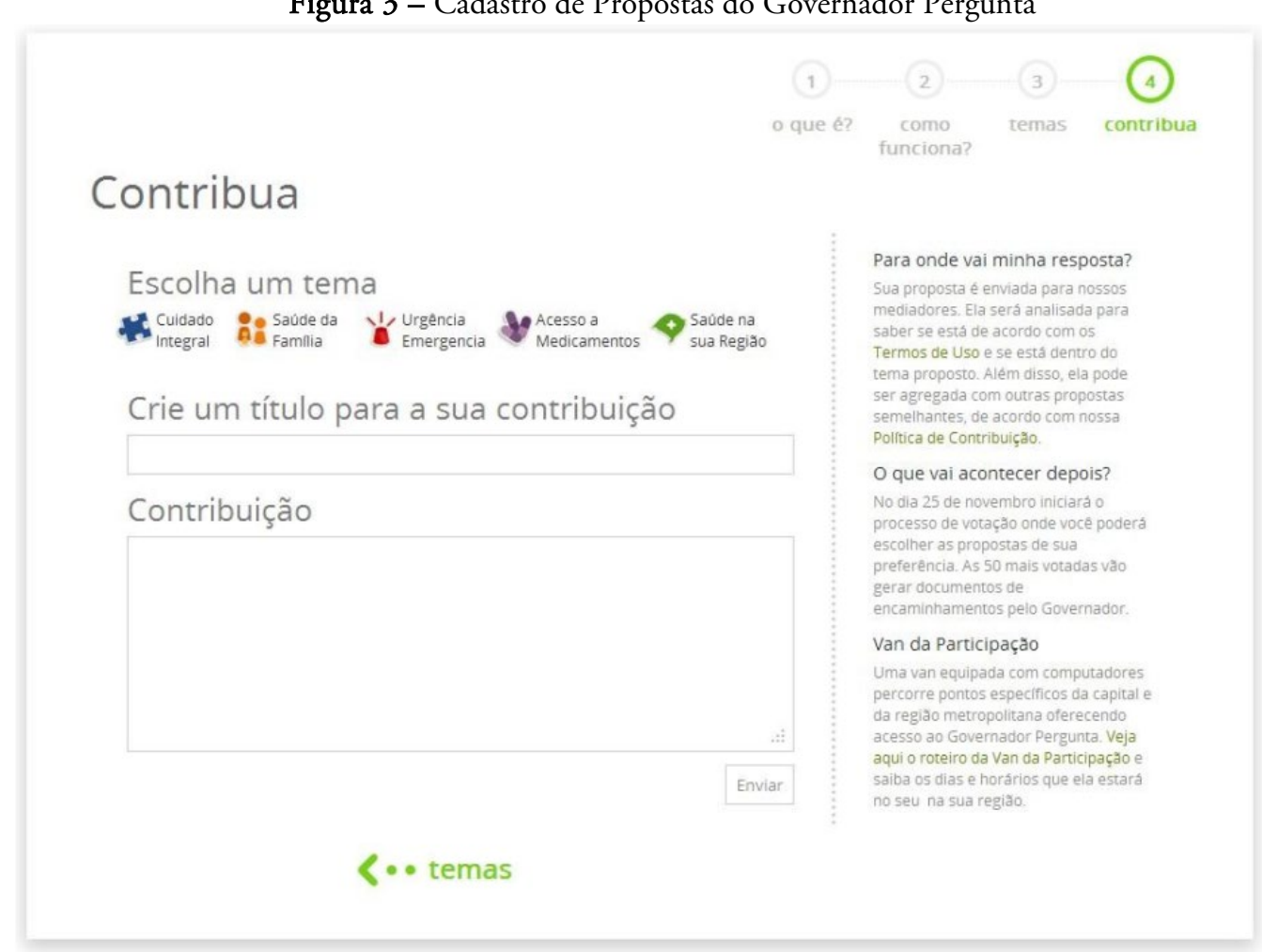

Fonte: Relatório da Sistemática do Diálogo “O Governador Pergunta” (2012a).

Um dos argumentos apresentados no início desta seção foi que a diversidade de temas contribuiu para o sucesso do Gabinete Digital e que, além disso, essa diversidade só foi possível porque o projeto esteve apoiado em uma articulaçáo interna transversal, envolvendo diferentes áreas de governo. Ou seja, ao contrário de outras experiências de e-participaçáo, esse náo foi um projeto de uma unidade de governo isolada, o que dificultaria a apresentação de resultados à população. Além disso, mesmo em uma consulta especifica sobre a saúde, como foi o caso da primeira edição do Governador Pergunta, percebe-se a preocupação, expressa em sua metodologia, de não direcionar excessivamente os termos da discussão pública, o que permitia ao participante contribuir com a consulta a partir de diferentes pontos de vista e interesses.

A metodologia de votaçáo apoiou-se no software desenvolvido no âmbito do projeto "All Our Ideas", da Universidade de Princeton, testado anteriormente nas cidades de Nova York (EUA) e Calgary (Canadá). Em suma, em vez de votar em 
propostas apresentadas em lista, o que tende a dificultar a compreensão geral da decisão (especialmente no caso de muitas opçóes), o participante do GD votava apenas em uma proposta de um par. Após votar, um novo par de opçóes era oferecido e novamente o participante poderia escolher apenas uma opção. E o processo se repetia até o limite de 50 votos. $\mathrm{Na}$ prática, assim, o sistema tendia a verificar quais eram as propostas mais votadas na comparação com outras e não apenas no número absoluto. A consulta foi dividida em duas etapas fundamentais: na primeira, o participante era convidado a apresentar proposiçóes; na segunda, havia a priorização das propostas com base na votação por pares (Figura 4).

Figura 4 - Sistema de Votação do Governador Pergunta

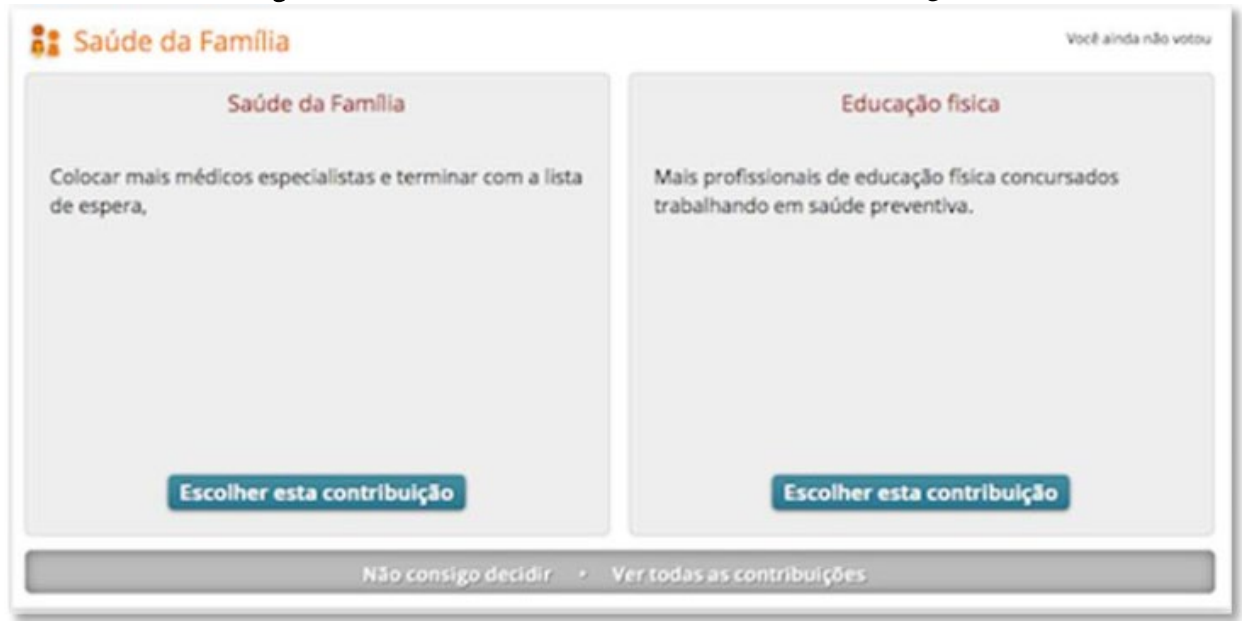

Fonte: Relatório da Sistemática do Diálogo “O Governador Pergunta” (2012a).

Assim, entre os dias 09 e 28 de novembro de 2011, foram cadastradas 1.405 proposiçóes oriundas de todas as regióes do estado. Por outro lado, entre os dias 28 de novembro e 10 de dezembro do mesmo ano, a ferramenta registrou 122.609 mil votos durante o período de priorização de proposta, tornando esta a maior consulta pública digital em números absolutos já realizada no país até então, segundo o governo do estado (DUARTE, 2011). Ao final da consulta, 50 proposiçôes foram priorizadas e seus autores convidados a participar de evento de apresentaçáo do resultado da consulta com a presença do governador e de secretários de estado e instituiçóes vinculadas à área da saúde. 
A variedade de questóes levantadas por meio das propostas e o debate que se deu em torno delas indicam que o objetivo do governo em estimular, entre os participantes, uma reflexão ampliada a respeito da agenda prioritária da saúde foi, ao menos parcialmente, cumprida. A distribuição das propostas entre os temas e os termos utilizados pelos participantes para cadastrar suas proposiçóes indicam que os assuntos foram bastante diversificados.

Portanto, com 120.000 votos e mais de 1400 perguntas cadastradas (Gráfico 4) na primeira consulta realizada no âmbito da ferramenta Governador Pergunta, o Gabinete Digital, que na primeira rodada da outra modalidade de consulta (Governador Responde) havia chegado a 6.637 votos recolhidos, alcançou um novo patamar em termos de adesão da população. Posteriormente, a segunda consulta do Governador Pergunta, que tratou da segurança no trânsito, foi ainda mais ampla e representativa do que a primeira, chegando a recolher mais de 240.000 votos (BAUMGARTEN, 2016).

Gráfico 4 - Evolução das propostas cadastradas na ferramenta Governador Pergunta (outubro-dezembro 2011)

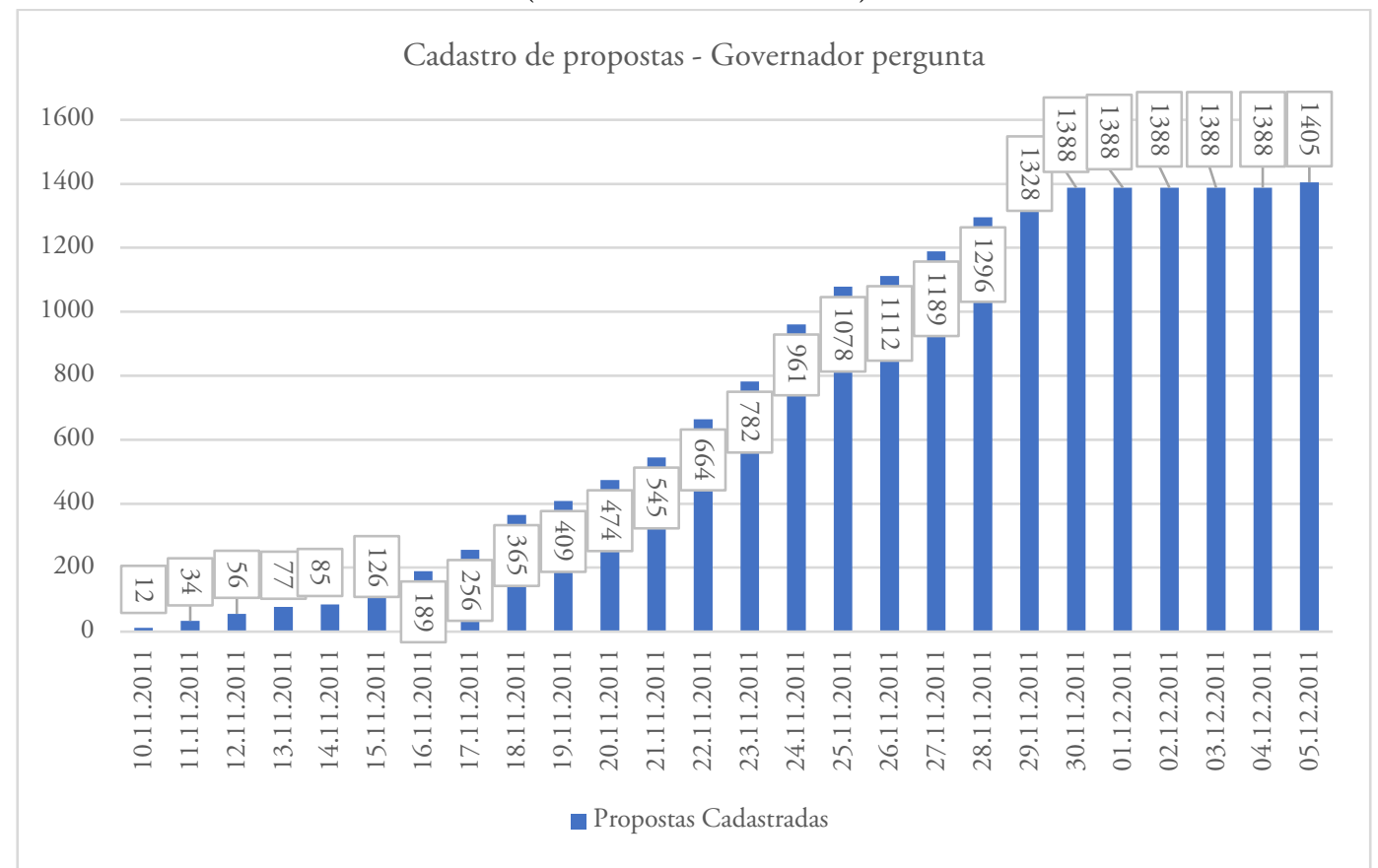

Fonte: $1^{\circ}$ Relatório de Monitoramento da Implementação e Avaliação do Gabinete Digital (2014). 
Os resultados obtidos pelo Governador Pergunta indicam que a nova ferramenta dá novo folego à experiência, evitando seu esvaziamento e consequente enfraquecimento institucional. A transversalidade do projeto (envolvendo diversas áreas do governo) que possibilita a diversidade de temas contribuiu para o fortalecimento institucional da iniciativa, relacionando-se com os fatores de sucesso analisados a seguir, notadamente, a mobilização institucional e a adesão dos servidores. Possibilitar ao público uma entrada única para um tipo de participação não restrito a áreas específicas de governo parece explicar, ao menos em parte, o sucesso desta experiência. É muito comum que projetos e-participaçáo estejam circunscritos a temas e áreas secundárias dos governos. Também é comum a proliferação de vários canais relacionados a temas setoriais, tornando a participação pouco inteligível (SPADA, ALEGRETTI, 2017).

O que parece ser possível afirmar no caso do Gabinete Digital é que a existência de uma entrada única para que a cidadania pudesse opinar sobre todos os temas relevantes do governo explica, em grande medida, os resultados obtidos. E isto não seria possível sem a integração de diferentes áreas do governo, possibilitada pela localização privilegiada do projeto - diretamente ligada ao Gabinete do Governador do Estado. A próxima seçâo busca expor como esse processo se deu na prática e de que forma os resultados e entregas à sociedade puderam ser construídos.

\section{Mobilização institucional e localização privilegiada}

A variedade de temas a que estava sujeito o Gabinete Digital - o que o diferencia de outras iniciativas que restringem a participação digital a temas específicos - e sua localização privilegiada - vinculado ao Gabinete do Governador do estado parecem ter contribuído para que o GD adquirisse força institucional capaz de gerar processos de internalização necessários ao atendimento das demandas oriundas da participação digital (AGGIO e SAMPAIO, 2014).

Essa internalização não seria possível sem uma efetiva mobilização institucional que esteve amparada por instrumentos normativos, dentre os quais se destacam o Decreto 48.056 de 24 de maio de 2011 (RIO GRANDE DO SUL, 2011a), que institui o Gabinete Digital, e o Decreto No 49.765, de 30 de outubro de 2012, que instituiu o Sistema Estadual de Participação Popular e Cidadã (RIO GRANDE DO SUL, 2012). Esse é um dos aspectos que o presente estudo ressalta enquanto fator que 
contribuiu para o sucesso do projeto analisado. Ambos os decretos evidenciam a relevância dada ao tema da participaçáo pelo governo do Rio Grande do Sul na ocasião.

Nas duas principais ferramentas disponibilizadas pelo projeto (Governador Responde e Governador Pergunta), é possível identificar um percurso desde a geração da demanda até seu atendimento, o que evidencia a mobilização interna necessária à efetivação do processo de participação. Nos dois casos selecionados para a análise, este percurso parece bem inteligível.

A primeira demanda a ser analisada é a pergunta mais votada na primeira edição do Governador Responde, que tratava da separaçáo do Corpo de Bombeiros da Polícia Militar local. A dinâmica era bem simples: o participante, através de um cadastro simples, enviava uma pergunta diretamente ao Governador do estado. A pergunta era disponibilizada no site, e a própria populaçáo escolhia qual ou quais perguntas o Governador responderia mensalmente através de vídeo. O cidadão que cadastrava a pergunta poderia mobilizar a populaçáo através das redes sociais, e-mail, etc., para votar. As perguntas eram analisadas de modo que estivessem de acordo com a Política de Contribuição e os Termos de Uso do projeto. Após 30 dias de votação, o Governador respondia à pergunta mais votada, garantindo uma espécie de "atendimento" da demanda. Outras perguntas poderiam ser agregadas por semelhança. A resposta em vídeo era publicada em até 10 dias após a contabilização de votos, conforme descrito no site do Gabinete Digital (FGV, 2014).

Em 16 de junho de 2011, uma pergunta questionando a estrutura organizativa do Corpo de Bombeiros do estado foi cadastrada. Na sequência, a pergunta ganhou o apoio da Associaçáo dos Bombeiros do Estado do Rio Grande do Sul (ABERGS) e se tornou a mais votada na primeira edição do Governador Responde. Como resposta, o governo instituiu, através do Decreto No 48.229, o "Grupo de Trabalho de Aconselhamento e Auxílio para Reorganização e Modernização do Corpo de Bombeiros" (RIO GRANDE DO SUL, 2011b), composto pela Chefia de Gabinete do Governador, Casa Civil, Casa Militar, Comando-Geral da Brigada Militar, Secretarias de Segurança Pública, Fazenda, Planejamento e Administração e Recursos Humanos, além de associaçóes representativas da Sociedade Civil.

O papel desse Grupo de Trabalho é o de participar das reunióes ordinárias, sempre apresentando, debatendo e formalizando as possíveis soluções e as propostas feitas pelas partes. O GT desempenha também um papel de essencial importância como lócus de intermediação de interesses como, por exemplo, dia 25 de outubro de 2011 quando as associaçóes dos Oficiais da 
Brigada Militar, dos Bombeiros do Estado do RS, Beneficente Antonio Mendes Filho, de Bombeiros Voluntários do RS e dos Bombeiros Resgatistas e Socorristas do RS apresentaram suas reivindicaçóes (FGV, 2011, p. 28).

Já em 28 de fevereiro de 2012, o Comando da Polícia Militar apresentava as respostas às principais reivindicaçóes e as providências implementadas ou em implementação para modernização e aumento de qualidade dos serviços do Corpo de Bombeiros. A Brigada Militar também foi responsável pela elaboração do Projeto de Lei enviada à Assembleia Legislativa. Em 2 de julho de 2012 (Dia Nacional dos Bombeiros), após diversas reuniôes do GT, o Governador do estado anunciou uma série de medidas para valorização e reestruturação da corporação no Rio Grande do Sul. O projeto de lei que visava ao atendimento à principal questáo levantada pela pergunta vencedora da primeira edição do Governador Responde foi enviado à Assembleia Legislativa do estado e seguiu em tramitação até ser aprovado em junho de 2014.

O desenho institucional do Gabinete Digital e a mobilização de diferentes unidades de governo foi o que garantiu efetividade ao processo de consulta analisado. A matriz de processos (Figura 5) a seguir torna mais explícita a dinâmica de mobilização interna ao governo, sem a qual náo seria possível realizar o atendimento à questáo levantada pela cidadania. 
Figura 5 - Matriz de macroprocessos do GD

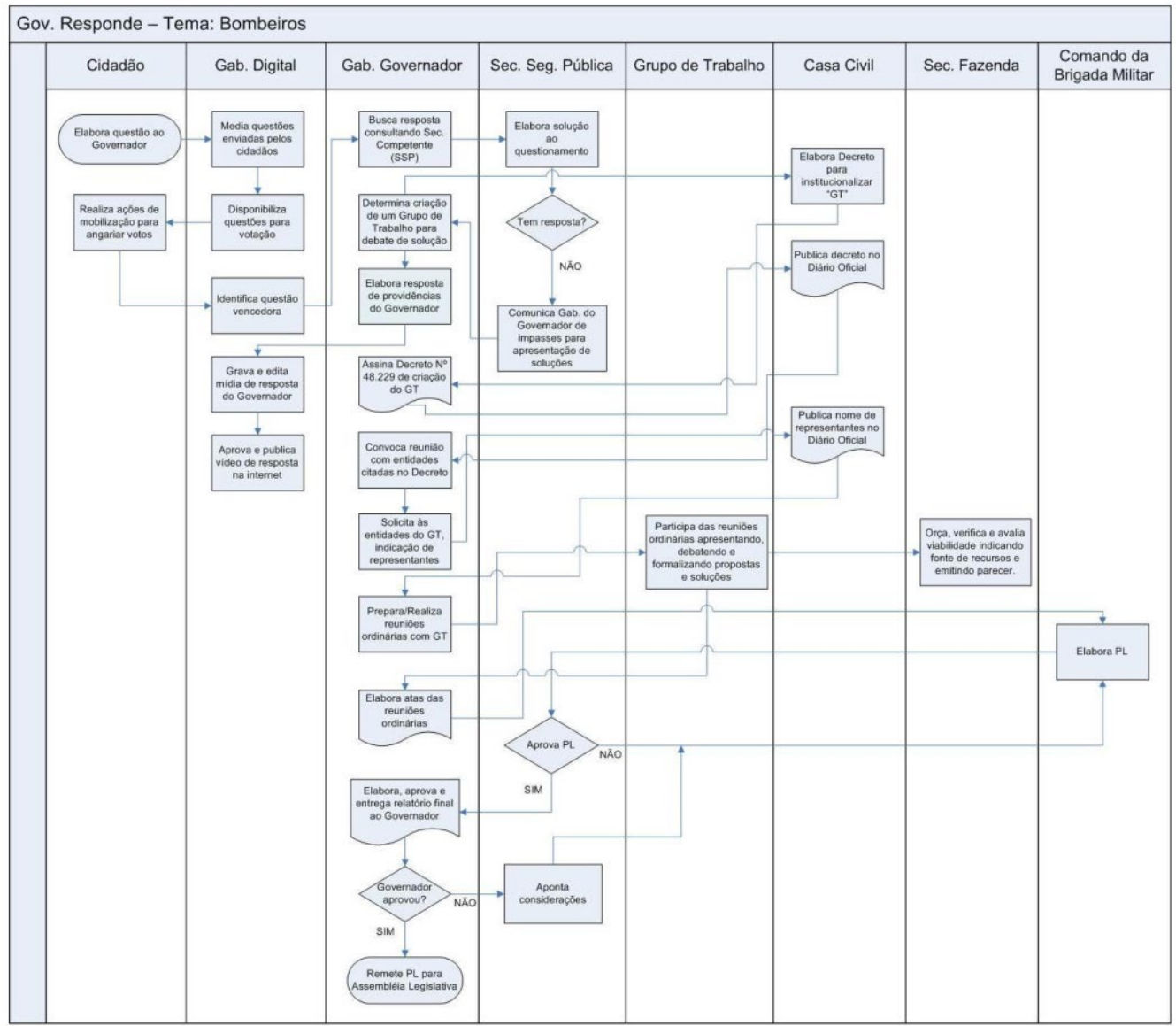

Fonte: $9^{\circ}$ Relatório de Monitoramento da Implementação e Avaliação do Gabinete Digital (2012b).

No segundo caso analisado nesta seção, o desenho institucional e a mobilização de diferentes unidades de governo são igualmente determinantes para obtenção de resultados efetivos e entregas à sociedade pelo projeto de e-participação. O Governador Pergunta, cuja dinâmica de funcionamento foi apresentada na seção anterior, se debruçou inicialmente sobre o atendimento na saúde.

No âmbito do Governador Pergunta, novamente, a matriz de macroprocessos2 (Figura 6) elaborada pelos gestores do Gabinete Digital para orientar o funcionamento da ferramenta nos informa a respeito do processo interno gerado para dar atendimento às questôes. Ele é fundamentalmente transversal e sugere um grau razoável de colaboração interna para funcionar. Conforme indica a matriz, quatro 
unidades de governo - três instâncias de primeiro escaláo e uma empresa pública foram mobilizadas diretamente para oferecer respostas ao processo de consulta, são elas: Gabinete do Governador, Secretaria de Comunicação, Secretaria de Saúde e Companhia de Processamento de Dados, Procergs.

Figura 6 - Matriz de macroprocessos do GD-2

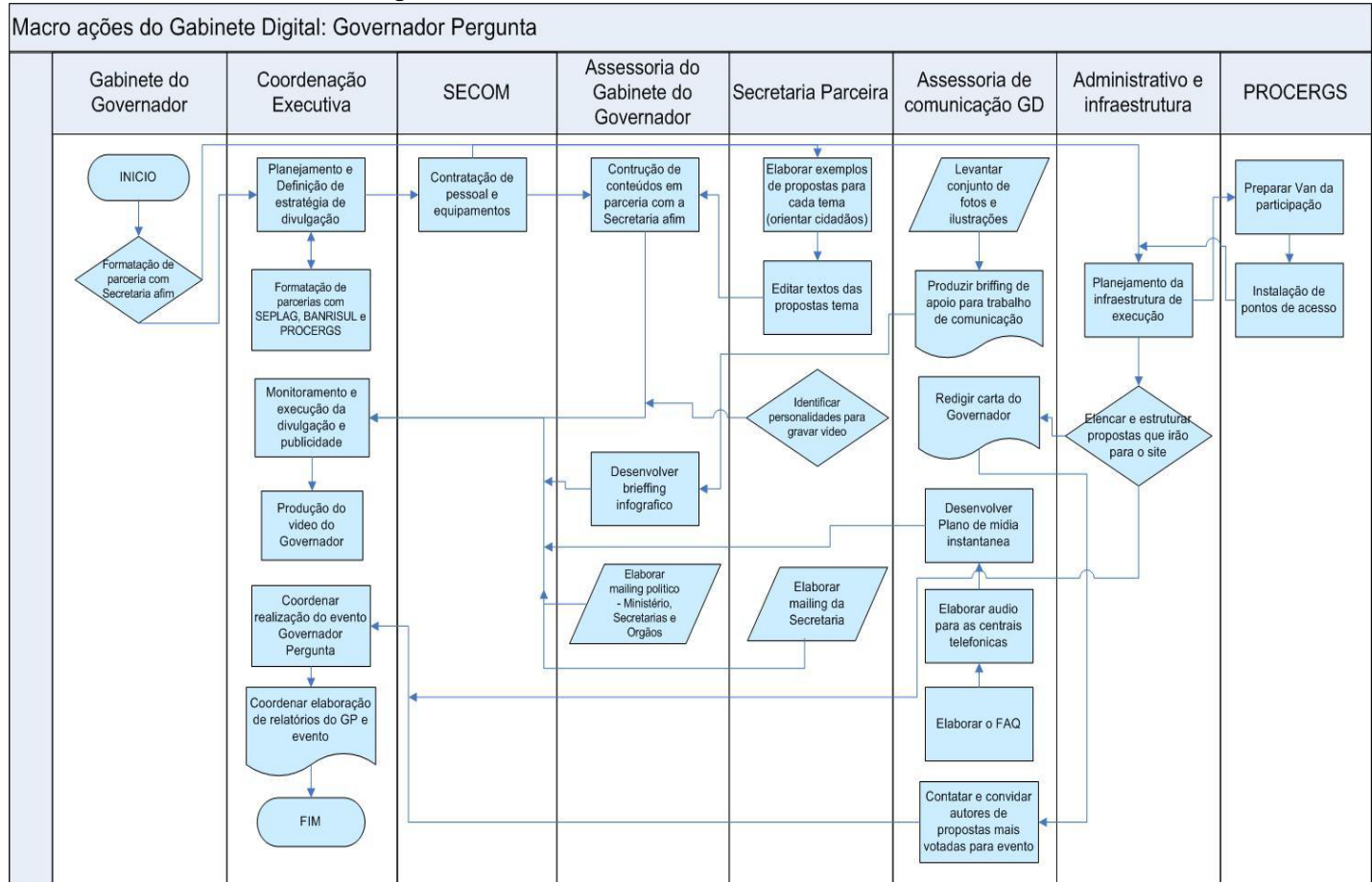

Fonte: $9^{\circ}$ Relatório de Monitoramento da Implementação e Avaliação do Gabinete Digital (2012b).

Assim, defende-se que a localização privilegiada (cf. AGGIO e SAMPAIO, 2014) da experiência de democracia digital do Rio Grande do Sul foi determinante para o êxito em sua capacidade de mobilização interna. $O$ projeto soube aproveitar o posicionamento junto ao Gabinete do Governador do estado para incidir sobre as estruturas de governo. A autoridade exercida sobre as demais unidades de governo, certamente, foi um elemento distintivo da atuação do Gabinete Digital, mas os resultados da experiência não teriam sido possíveis sem que houvesse um trabalho de sensibilização dos servidores do estado que contribuísse para vencer eventuais 
resistências internas (ver também BAUMGARTEN, 2016), o que será revisado a seguir.

\section{Adesão de servidores e dirigentes do governo}

É muito comum encontrarmos, nas experiências de democracia digital, indícios de resistência por parte do corpo de servidores e dirigentes de governo às mudanças suscitadas por mecanismos de consulta e participação da sociedade na formulaçáo e execução de políticas públicas (FARIA et al., 2016; FOUNTAIN, 2001; TOOTS, 2019; VIDIASOVA et al., 2017). A experiência do Gabinete Digital também enfrentou resistências internas em especial nos dois anos iniciais do projeto, segundo a literatura já disponível sobre o projeto. No entanto, o reconhecimento externo (que se manifesta nos diversos prêmios recebidos), a adesão da população (cuja participação nas consultas públicas foi aumentando a cada edição) e os números referentes à participação em momentos-chave, como os protestos de 2013 (quando uma audiência pública organizada pelo GD contou com mais de meio milhão de acessos na plataforma $)^{2}$ foram, paulatinamente, minando as resistências iniciais e ampliando o apoio interno ao projeto. Essa hipótese foi confirmada pelos resultados de um websurvey realizado já no ano de 2014 , entre 24 de julho e 18 de agosto daquele ano, envolvendo 343 dirigentes do governo (FGV, 2014).

Os números atestam que, após três anos e meio de desenvolvimento do projeto, o Gabinete Digital havia adquirido um considerável nível de conhecimento e adesão dos quadros do governo a seus objetivos. As principais questóes levantadas pelo websurvey se referem ao nível de conhecimento e apoio interno à experiência de democracia digital desenvolvida pelo governo do Rio Grande do Sul desde 2011. A pesquisa foi organizada pela Fundaçáo Getúlio Vargas, FGV, e constam do Relatório Técnico Parcial de Estudo Comparativo de 2014 (FGV, 2014). O nível de conhecimento do projeto é informado pelo Gráfico 5, a seguir:

2 http://g1.globo.com/rs/rio-grande-do-sul/noticia/2013/07/governo-do-rs-lanca-consulta-publicasobre-reforma-politica.html. Acesso 14 de abril de 2021. 
Gráfico 5 - Nível de conhecimento entre os servidores (2014)

O Governo do Estado do Rio Grande do Sul possui um site na internet chamado Gabinete Digital, que funciona como um canal de participação e diálogo entre a população e o governo. Sobre o Gabinete Digital, o(a) sr(a) diria que:

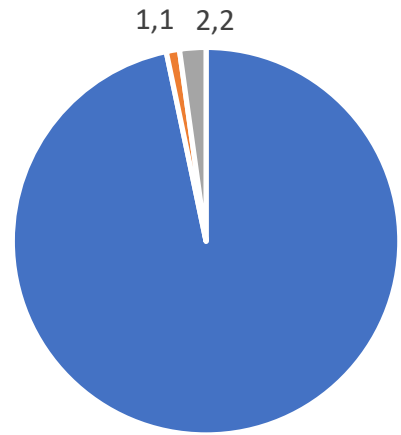

96,7

- Já tinha ouvido falar a respeito n É a primeira vez que ouve falar घ Ns/Nr

Fonte: $1^{\circ}$ Relatório Técnico Parcial de Estudo Comparativo (FGV, 2014).

O resultado mostra que a ampla maioria dos servidores havia se colocado em contato com o projeto de democracia digital. Os que responderam que "já tinham ouvido falar a respeito" representam $96,7 \%$ do total dos entrevistados. Apenas 1,1\% responderam "É a primeira vez que ouve falar". E, finalmente, 2,2\% marcaram a opçáo "Não sabe" ou "Prefiro não responder". A pergunta seguinte buscou identificar o sentimento dos entrevistados em relação à plataforma, levantando, assim, o sentimento predominante dos dirigentes de governo em relação ao Gabinete Digital. O resultado indica uma elevada capacidade de sensibilizaçáo interna. A pesquisa ouviu gestores e dirigentes dos diferentes órgãos de governo, distribuídos pelas diversas regiôes do estado. 
Gráfico 6 - Sentimento dos dirigentes de governo em relação ao Gabinete Digital (2014)

E como o(a) sr(a) avalia o Gabinete Digital do Governo do Estado do Rio Grande do Sul?

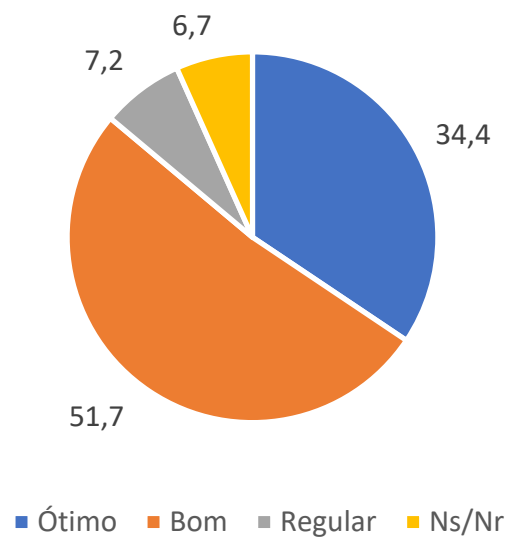

Fonte: $1^{\circ}$ Relatório Técnico Parcial de Estudo Comparativo (FGV, 2014).

Aqui, percebe-se que 34,4\% dos entrevistados avaliaram como "Ótimo" o GD. Outros $51,7 \%$ dos entrevistados avaliaram o projeto como "Bom". Outros 7,2\% avaliaram o GD como Regular e 6,7\% responderam "Não sabe" ou "Prefiro não responder". Os resultados do websurvey confirmam a impressão de que o Gabinete Digital logrou obter apoio entre os quadros de governo responsáveis pelas áreas finalísticas e isso parece ter sido um elemento importante para o êxito de inúmeras açôes desenvolvidas no âmbito do projeto.

Em outra pergunta, os entrevistados foram instados a relacionar o projeto ao desenvolvimento de suas atividades enquanto servidores. Nesse caso, a pergunta buscou relacionar especificamente a ferramenta "De olho nas Obras", lançada em 2013, ao trabalho dos servidores. De Olho nas Obras era uma ferramenta que possibilitava o acompanhamento pela população da execução das obras promovidas pelo governo. Era possível enviar informaçôes, enviar sugestôes, comentários, fotos, vídeos e obter respostas do governo a respeito do andamento e execução dos projetos. 
Gráfico 7 - Sentimento em relação à ferramenta De Olho nas Obras do GD (2014) O Gabinete Digital possui uma ferramenta de transparência e
fiscalização chamada "De Olho nas Obras". O(A) Sr(a) considera
que esta ferramenta contribui para o seu trabalho enquanto servidor público?

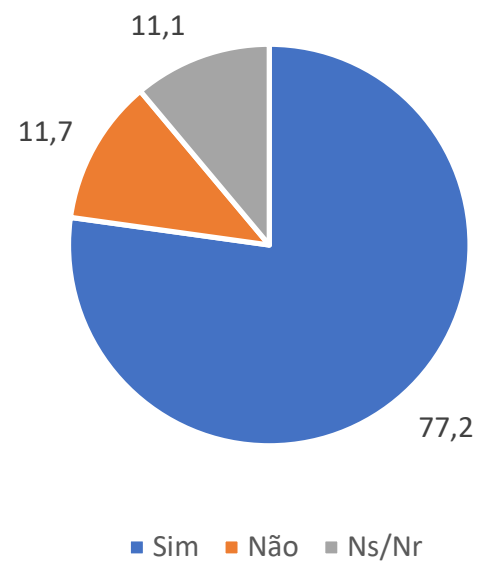

Fonte: $1^{\circ}$ Relatório Técnico Parcial de Estudo Comparativo (FGV, 2014).

Novamente, uma ampla maioria, $77,2 \%$, avaliou a plataforma como positiva. Apenas $11,7 \%$ declarou não ver implicaçóes positivas da plataforma sobre o desenvolvimento de seu trabalho. Portanto, os resultados do websurvey confirmam a impressáo de que o Gabinete Digital logrou obter apoio entre os quadros de governo responsáveis pelas áreas finalísticas e isso parece ter sido um elemento importante para o êxito de inúmeras açóes desenvolvidas no âmbito do projeto.

\section{Considerações Finais}

O objetivo deste artigo foi levantar hipóteses e questóes de pesquisa referentes à avaliação de iniciativas de democracia digital tendo como referência alguns dos aspectos observados na experiência do Gabinete Digital. Buscou-se proceder a uma abordagem de estudo de caso sobre o objeto, avaliando-se diferentes tipos de dados existentes sobre o mesmo, indicando a existência de três características vitais, que contribuem para dotar o projeto de suficiente capacidade de coordenaçáo sobre as diferentes áreas de governo. Essas características são: (a) transversalidade e diversidade de temas; (b) mobilização institucional e localização privilegiada; e (c) adesão dos 
servidores e dirigentes de governo. Nosso intuito foi desenvolver questóes internas à gestão do instrumento de democracia digital, elementos que frequentemente são deixados em segundo plano por estudos e reflexôes desta natureza que, em geral, se ocupam da ponta final do processo participativo. O GD, desde sua criação, buscou ser uma iniciativa transversal, incidindo sobre diversas áreas de governo (o que entendemos ser um dos fatores de sucesso da experiência), e aberta a um variado conjunto de questôes. Entretanto, ambas as características não são possíveis sem a mobilização institucional e a adesão dos servidores e dirigentes de governo.

Como sabemos, há todos os tipos de resistências institucionais a novas formas destinadas a realizar atividades já rotineiras. Porém, enquanto muito se fala da resistência de agentes políticos para compartilharem o poder em instituiçóes participativas ou em iniciativas de democracia digital (COLEMAN e BLUMLER, 2009; GOMES, 2011), muitas vezes se ignora o papel fundamental dos agentes burocráticos para o sucesso de semelhantes iniciativas (FARIA et al., 2016; PANOPOULOU et al., 2014; TOOTS, 2019; VIDIASOVA et al., 2017). Como bem explicitado por Faria e colegas (2016), os agentes burocráticos podem ser aqueles mais resistentes às mudanças institucionais ou, alternativamente, podem ser justamente os incubadores da inovação institucional e democrática. A questão passa por compreendêlos como atores importantes a quaisquer processos de inovação nas instituições.

A mobilização institucional seria um foco mais interno do que se costuma chamar mais genericamente de vontade política e demanda aquilo que Aggio e Sampaio (2014) definiram como posição institucional privilegiada. Em suma, qualquer instrumento participativo (digital ou não) dificilmente dependerá exclusivamente de um único órgão (e.g. uma única secretaria) devido à complexidade das máquinas governamentais. Usualmente, o ponto sobre os quais os cidadãos estão participando e decidindo tende a ter impactos diretos ou indiretos sobre vários órgãos e é vital que eles já estejam mobilizados para atender a essas demandas. O risco é ocorrer aquilo que tende a ser muito visto em processos de orçamentos participativos pelo país: os cidadãos participam, aprovam obras, mas não há orçamento e/ou celeridade nos processos que gerem a execução dessa obra (e.g. licitação da empresa para realizar a obra). Isso tende a gerar um efeito negativo sobre os cidadãos. A posição institucional privilegiada é importante para que esses fluxos sejam respeitados, já que vão no sentido top-down na hierarquia institucional. Ela também tende a mitigar uma participação multicanal descontrolada, como alertado por Spada e Allegretti (2017), na qual os canais de participação começam a concorrer entre si. Há, por outro lado, claro, menos espaço 
para inovação e criatividade (Freitas, 2021). Não se tratou de algo discutido neste texto, mas o GD tentou mitigar isso com forte envolvimento da sociedade civil, principalmente em temas contemporâneos, como hackativismo, software livre e transparência ativa (AGGIO e SAMPAIO 2014; BAUMGARTEN, 2016; RODEGHERI e OLIVEIRA, 2015; SANTOS et al., 2015).

A resistência institucional é inversamente proporcional à adesão dos agentes institucionais. Se o funcionalismo percebe a ferramenta como importante, a tendência é criar um ambiente propicio a sua realização. Em outras palavras, frequentemente os processos inovadores de democracia digital vão exigir que os agentes institucionais saiam de suas zonas de conforto e, igualmente, podem demandar tarefas extras. Logo, a tendência é que o agente em questão não esteja particularmente feliz com as novas atribuiçóes (FARIA et al., 2016). Se é verdade que a posição institucional privilegiada tende a assegurar que um determinado órgáo obedeça a uma demanda, isso não quer dizer, necessariamente, que a resposta de outros órgãos implicados será eficaz. Porém, isso pode ser mitigado ou mesmo superado se os agentes envolvidos tiverem uma percepção positiva a respeito da iniciativa (VIDIASOVA et al., 2017). No caso do GD, isso se deu de forma que foram os próprios funcionários públicos os primeiros a aderirem de forma consolidada à plataforma. É importante denotar que isso ocorreu sem a necessidade de uma institucionalização formal, como a criaçáo de leis ou aparatos estatais.

Assim, parece correto afirmar que o sucesso de experimentos de democracia digital, em específico, e mesmo de inovaçôes democráticas, no geral, podem ser facilitadas pela localização privilegiada das experiências em termos institucionais. Mais do que isso, é preciso reunir capacidade de comando, autoridade política e sensibilizar os servidores públicos envolvidos com os processos de tomada de decisão, questôes que frequentemente ficam escondidas dentro do termo "vontade política". Estes e outros elementos definem se uma experiência terá ou não suficiente capacidade de coordenação, algo que reputamos fundamental para que tais iniciativas adquiram força e legitimidade para produzirem resultados efetivos à sociedade. 
Vinicius Wu é Doutorando em Comunicação Social pela PUC-Rio. Pesquisador do Instituto Nacional de Ciência e Tecnologia em Democracia Digital (INCT.DD). Foi idealizador e Coordenador Geral do Gabinete Digital do Rio Grande do Sul. E-mail: viniciuswu@gmail.com.

Rafael Cardoso Sampaio é Professor do Departamento de Ciência Politica da Universidade Federal do Paraná (UFPR). É professor do Programa de Pós-Graduação em Ciência Política e do Programa de Pós-Graduação em Comunicação da UFPR. Pesquisador do INCT.DD. Bolsista de Produtividade em Pesquisa do CNPq-Nível 2. E-mail: cardosososampaio@gmail.com.

\section{Referências}

AGGIO, Camilo; SAMPAIO, Rafael. A democracia digital do gabinete do governador: o perfil e os limites de um modelo consultivo de participação. In: SILVEIRA, Sérgio; BRAGA, Sérgio; PENTEADO, Cláudio. (Org.). Cultura, política e ativismo nas redes sociais. São Paulo: Fundação Perseu Abramo, 2014, p. 215-242.

ALMADA, Maria; CARREIRO, Rodrigo; BARROS, Samuel; GOMES, Wilson. Democracia digital no Brasil: obrigação legal, pressão política e viabilidade tecnológica. MATRIZes, v. 13, n. 3, p. 161-181, 2019.

ÅSTRÖM, Joachim; GRÖNLUND, Åke. Online consultations in local government: What works, when, and why. In: COLEMAN, S.; SHANE, P. (org.) Connecting democracy: Online consultation and the flow of political communication, v. 75, 2012, p. 75-96.

BAUMGARTEN, Marcelo. Reflexôes sobre o papel do estado na constituiçáo do campo democrático digital: um estudo de caso do gabinete digital do Rio Grande do Sul. 2016. 293f. Tese (Doutorado em Administração) - Programa de Pós-Graduação em Administração, Universidade Federal do Rio Grande do Sul, Porto Alegre, 2016.

BRISOLA, Anna; LEAL, Taís; PACHECO, Evellyn; CRISPINO, Fabiana. Internet e participação: uma análise do portal Gabinete Digital. Anagrama, v. 6, n. 1, p. 1-15, 2012.

COCCO, Giuseppe. (org.). Gabinete digital: análise de uma experiência. Porto Alegre: Companhia Riograndense de Artes Gráfica, 2013.

COLEMAN, Stephen, BRUMLER, Jay. The internet and democratic citizenship: theory, practice and policy. Cambridge: Cambridge University Press, 2009. 
DUARTE, Rachel. Gabinete Digital: sugestôes virtuais se tornam prioridades reais para saúde dos gaúchos. Sul Vinte e um, 14 dez. de 2011. Disponível em: <https://www.sul21.com.br/noticias/2011/12/gabinete-digital-sugestoes-virtuais-se-tornamprioridades-reais-para-a-saude-dos-gauchos/>. Acesso em: 07 abr. 2021.

FARIA, Cristiano; REHBEIN-SATHLER, André; RODRIGUES, Malena. Netizen em ação: hackeando o parlamento a partir de dentro. In: SILVA, S. P.; BRAGATTO, R. C.; SAMPAIO, R. C. (Org.). Democracia digital, comunicação política e redes: teoria e prática. 1ed. Rio de Janeiro: Folio Digital: Letra e Imagem, 2016, p. 393-417.

FGV, FUNDAÇÃO GETULIO VARGAS. $1^{\circ}$ Relatório de Monitoramento da Implementaçáo e Avaliação do Gabinete Digital, Rio de Janeiro, 23 de novembro de 2011.

FGV, FUNDAÇÃO GETULIO VARGAS. Relatório da Sistemática do Diálogo "O Governador Pergunta”, Rio de Janeiro, 10 maio de 2012a.

FGV, FUNDAÇÃO GETULIO VARGAS. $9^{\circ}$ Relatório de Monitoramento da Implementação e Avaliaçáo do Gabinete Digital, Rio de Janeiro, 3 de setembro de $2012 \mathrm{~b}$.

FGV, FUNDAÇÃO GETULIO VARGAS. $1^{\circ}$ Relatório Técnico Parcial de Estudo Comparativo, Rio de Janeiro, 2 de setembro de 2014.

FOUNTAIN, Jane. Building the virtual state. Washington: Brookings Institution, 2001.

FREITAS, Christiana Soares. Inovaçóes Democráticas Digitais para Transparência Governamental na América Latina e Caribe: Possibilidades e Desafios. Comunicação \& Inovação, v. 22, n. 48, p. 80-96, 2021.

GOMES, Wilson. Participação política online: questóes e hipóteses de trabalho. In: MAIA, R.C.M; GOMES, W.; MARQUES, F.P.J.A. (Org.). Internet e participação política no Brasil. Porto Alegre: Sulina, 2011, p. 19-46.

JERÔNIMO, Luciana. Diálogo temático on-line na consulta pública digital: um estudo sobre relaçóes entre enunciados do governo e dos cidadáos (O caso do "Governador Pergunta" no site "Gabinete Digital” do RS). 2016. 452p. Tese (Doutorado em Comunicação Social) - Programa de Programa de Pós-Graduação em Comunicação, Pontifícia Universidade Católica do Rio Grande do Sul, Porto Alegre, 2016.

LÜCHMANN, Lígia Helena Hahn. Interfaces Socioestatais e Instituiçôes Participativas: Dimensões Analíticas. Lua Nova, v. 109, p. 13-49, 2020.

PANOPOULOU, Eleni; TAMBOURIS, Efthimios; TARABANIS, Konstantinos. Success factors in designing eParticipation initiatives. Information and Organization, v. 24, n. 4, p. 195-213, 2014.

RIO GRANDE DO SUL. Decreto $n^{\circ} 48.056$, de 24 de maio de 2011. Institui o Gabinete Digital do governador do Estado e a Comissão Permanente de Cultura e Governança Digital. Diário Oficial do Estado, Porto Alegre, RS n. ${ }^{\circ} 101$, de 24 de maio de 2011 a.

RIO GRANDE DO SUL. Decreto No 48.229, de 10 de agosto de 2011. Institui Grupo de Trabalho de Aconselhamento e Auxílio para Reorganização e Modernização do Corpo de Bombeiros. Diário Oficial do Estado, Porto Alegre, RS n. ${ }^{\circ} 154,10$ de agosto de 2011 b.

RIO GRANDE DO SUL. Decreto No 49.765, de 30 de outubro de 2012. Institui o Sistema Estadual de Participação Popular e Cidadã - SISPARCI. Diário Oficial do Estado, Porto Alegre, RS n. o 210, de 31 de outubro de 2012. 
RODEGHERI, Letícia; OLIVEIRA, Rafael. A experiência do Gabinete Digital do Estado do Rio Grande do Sul e a construção da cibercidadania no Brasil. Pensar-Revista de Ciências Jurídicas, v. 19, n. 3, p. 721-749, 2015.

ROTENBERG, Marcelo Rabelo. Democracia digital e participação cidadá: um estudo de caso do governo do Estado do Rio Grande do Sul. 2014. 113p. Dissertaçáo (Mestrado em Administração Pública) - Escola Brasileira de Administração Pública e de Empresas, Fundação Getúlio Vargas, Rio de Janeiro, 2014.

SANTOS, Jorge; CORSO, Kathiane; BEHR, Ariel; FARIAS, Everton. Cidadãos em Rede: o gabinete digital do Estado do Rio Grande do Sul como instrumento de democracia digital. Revista Democracia Digital e Governo Eletrônico, v. 1, n. 12, p. 150-182, 2015.

SMITH, Graham. Democratic innovations: Designing institutions for citizen participation. Cambridge: Cambridge University Press, 2009.

SPADA, Paolo; ALLEGRETTI, Giovanni. Integrating multiple channels of engagement in democratic innovations: Opportunities and challenges. In: ADRIA, Marco; MAO, Yuping (org.). Handbook of research on citizen engagement and public participation in the era of new media. Hershey: IGI Global. 2017, p. 20-37.

TOOTS, Maarja. Why E-participation systems fail: The case of Estonia's Osale. Government Information Quarterly, 2019.

SMITH, Angus; MACINTOSH, Ann. Existing e-participation practices with relevance to Web. International Teledemocracy Centre, Napier University. 2007.

VIDIASOVA, Lyudmila; TRUTNEV, Dmitrii; VIDIASOV, Evgenii. Revealing the Factors Influencing E-participation Development in Russia. In: International Conference on Electronic Participation. Springer: Cham, 2017, p. 65-74.

ZIMMERMANN, Hans-Dieter. Evaluation of an eParticipation Project Against eParticipation Success Factors. In: International Conference on Electronic Governance and Open Society: Challenges in Eurasia. Springer: Cham, 2018, p. 295-307.

Texto recebido em 29 de dezembro de 2020. Aprovado em 22 de março de 2021. 